\title{
LEKSIOLOGI BAHASA TINJAUAN VARIASI LAFAZ DALAM HADIS
}

\author{
Oleh: Firdaus ${ }^{1}$ \\ ${ }^{1}$ Institut Agama Islam Muhammadiyah Sinjai, \\ Jl. Sultan Hasanuddin, No. 20 Balangnipa, Sinjai \\ E-Mail:doktorfirdaus@gmail.com, Tlp.: +628114188997
}

\begin{abstract}
Abstrak
Al-Quran dan al-Hadits adalah pedoman muslim yang diturunkan dengan menggunakan bahasa Arab, penuh dengan kaidah tata bahasa yang agung dan susunan ungkapan yang sangat indah sehingga ketika akan memahami maksudnya diperlukan penguasaan bahasa Arab. leksiologi kata dalam hadis sangat ditentukan oleh lafadz-lafadz basyir r, al-jinnah, nadzir r, al-dua, AlMunkar, tarbiyah, Al-Nahy, al-Khalifah, dan ta'lim. Kata basȳir dan beberapa derivasinya memiliki dua unsur makna kunci yaitu; (1) adanya proses menampakkan, memberitahukan, atau memberikan informasi, serta (2) sesuatu yang diinformasikan bersifat menggembirakan. Atau kalau kita mengambil pendapat Al-Thabary terdapat unsur ketiga yaitu (3) informasi yang menggembirakan tersebut sebelumnya tidak diketahui oleh penerima. Kata indzār lebih sering digunakan untuk mengartikulasikan pemberian peringatan atau informasi yang menakutkan, meskipun juga bisa berarti pemberian informasi secara mutlak. Atau dalam konteks beberapa ayat al-Qur'an bisa memiliki arti memberikan peringatan berupa pengajaran pesan-pesan agama Islam. Sedangkan kata Ta'lim secara umum hanya terbatas pada pengajaran dan pendidikan kognitif semata-mata. Hal ini memberikan pemahaman bahwa ta'lim hanya mengedepankan proses pengalihan ilmu pengetahuan dari pengajar (mu'alim) dan yang diajar (muta'alim).
\end{abstract}

\section{Kata Kunci: Leksiologi, Lafaz, Hadis}

\section{PENDAHULUAN}

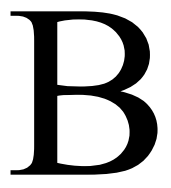

ahasa adalah alat komunikasi yang digunakan dalam berinteraksi antar sesama manusia. Kebanyakan orang melakukan interaksi tanpa pengetahuan dan kemampuan bahasa yang minim sehingga terjadi kesalahpahaman atau perselisihan. Maka perlu ditempuh upayaupaya untuk mempelajari bahasa itu sendiri. Demikian halnya dengan memahami bahasa Arab.

Al-Quran dan al-Hadis adalah pedoman muslim yang diturunkan dengan menggunakan bahasa Arab, penuh dengan kaidah tata bahasa yang agung dan susunan ungkapan yang sangat indah sehingga ketika akan memahami maksudnya diperlukan penguasaan bahasa Arab.

Kandungan al-Quran dan al-Hadis bervariatif, ada yang menyangkut tentang tauhid, iman, akhlak, sejarah, syariat, dll. Namun dalam tulisan ini penulis tidak membahas tentang isi kandungan al-Quran dan al-Hadits akan tetapi ini hanya sedikit gambaran tentang kosa kata bahasa arab yang ada di dalamnya.

Setelah melihat uraian di atas maka dapat kita tarik beberapa pokok bahasan yang dijadikan pokok masalah yaitu bagaimana bentuk variasi contoh Lafaz-lafaz dalam hadits? 


\section{PEMBAHASAN}

\section{A. Basȳir}

Kata basȳir (بشير) berasal dari akar kata bā sȳnn rāa (ب ش ر) yang derivasinya membentuk beberapa kata seperti basyar (manusia), basyarah (bagian luar kulit manusia), mubāsyarah (hubungan suami istri), bisyr (keceriaan wajah), busyrā (kabar gembira), basysyara (menampakkan hasil) dan lain-lain.1 Ibn Fāris (329-395H) menyatakan bahwa akar kata bō sȳ̄n rā memiliki arti dasar "muncul atau terlihatnya sesuatu bersama keindahan” ( ظهور الثنّيء مع حُسْنِ وجمال).2 Dan dari makna dasar inilah makna-makna derivasi kata $b \bar{a}$ sȳ̄n rā disandarkan. Sedangkan makna dari basysyara seperti dalam

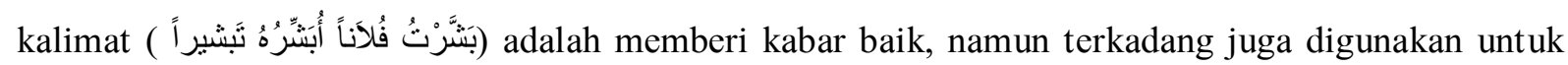
mengartikulasikan pemberian kabar buruk sebagai bentuk celaan.

Berbeda dengan Ibn Fāris, Al-Rāghib Al-Asfahāni (w.502 H) lebih melihat kata basyarah yang

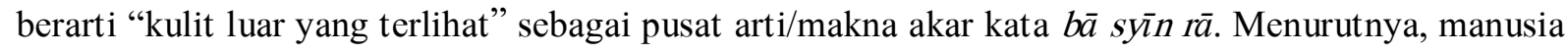
disebut basyar (بشر) karena kulitnya yang terlihat jelas tanpa terhalang oleh rambut, berbeda dengan hewan yang tertutup oleh rambut ataupun bulu. Maka tidak mengherankan pula ketika menjelaskan makna kata kerja absyara (أبشر) dan basy-syara (بشر ), yang menjadi muasal kata basyñr, beliau memaknainya dengan "memberikan kabar gembira yang membuat kulit muka menjadi berseri-seri, hal ini dikarenakan jiwa manusia ketika dalam kondisi bergembira darahnya menyebar di permukaan kulit mukanya sebagai mana tersebarnya air getah pada batang pohon”.3 Al-Asfahāny menambahkan bahwa apa-apa yang dibawa oleh seorang oleh seorang pembawa berita gembira (mubasysyir) disebut dengan busyrā (بشرى) atau bisyārah (بشارة).

Pendapat sedikit berbeda dikemukakan oleh Ibn Jarīr al-Thabariy (224-310 H) ketika menafsirkan QS. Al-Baqarah/2: 97. Secara lebih tajam dan spesifik beliau menyatakan bahwa menurut tradisi bahasa Arab kata al-bisyārah (البشارة) diartikan sebagai "pemberitahuan kepada seseorang seseorang tentang berita yang belum pernah diketahuinya dan dapat membuatnya gembira, sebelum dia mendengarnya dari orang lain atau mengetahuinya dari orang lain".4

Dari uraian diatas dapat disimpulkan bahwa kata basyīr dan beberapa derivasinya memiliki dua unsur makna kunci yaitu; (1) adanya proses menampakkan, memberitahukan, atau memberikan informasi, serta (2) sesuatu yang diinformasikan bersifat menggembirakan. Atau kalau kita mengambil pendapat Al-Thabary terdapat unsur ketiga yaitu (3) informasi yang menggembirakan tersebut sebelumnya tidak diketahui oleh penerima.

1 Ibrāhīm Musthafā, dkk., (Majma' Al-Lughah Al-Arabiyah Mesir), Al-Mu'jam Al-Wasith, (Istanbul, Dar al-Da'wah, 1989), h.57-58.

2 Abū al-Husayn Ahmad ibn Fāris ibn Zakariyā, Maqāȳis al-Lughah, Tahqiq: Abd al-Salām Muhamad Hārūn, (Beirut, Dār Al-Fikr, 1979M/1399H) Jilid I, h. 251

3 Al-Husain ibn Muhamad ibn Al-Mufadlal, Abū al-Qāsim Al-Rāghib Al-Asfahāni, Mufradāt Alfādh alQur'ān, (Software Al-Maktabah Al-Shāmela Edisi 3.13). Teks aslinya berbunyi:

$$
\text { وأبشرت الرجل وبشرته وبشرته: أخبرته بسار بسط بشرة وجهه، وذلك أن النفس إذا سرت انتشر الدم فيها انتشار الماء في الشجر }
$$

4 Muhamad ibn Jarīr ibn Yazīd ibn Katsīr bin Ghālib al-Amily, Abū Ja'far al-Thabary, Jāmi' al-Bayān fí Ta'wīl Al-Qur'ān, (Beirut, Muassasah al-Risālah, 2000), Juz. II, h. 393 
Rasulullah Saw. bersabda:

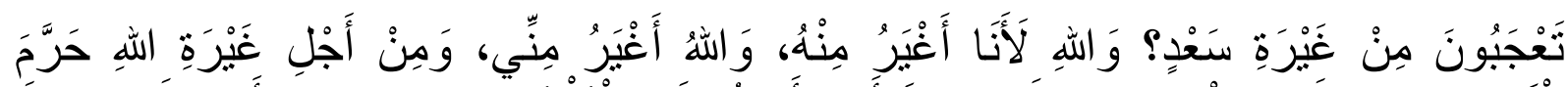

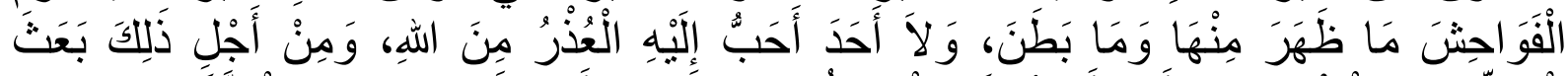

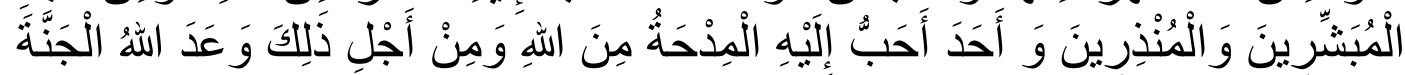

Artinya:

"Kalian merasa heran dengan kecemburuan Sa'd? Demi Allah, aku lebih cemburu darinya, dan Allah Subhanahu wata'alalebih cemburu dariku. Karena kecemburuan Allah Subhanahu wata'ala, Dia mengharamkan segala perbuatan keji yang tampak dan yang tersembunyi. Tiada satu pun yang lebih senang menerima uzur dari Allah Subhanahu wata'ala. Oleh karena itu, Dia mengutus para pembawa berita gembira dan pemberi peringatan, dan tidak satu pun yang paling menyenangi pujian dari Allah Subhanahu wata'ala, karena itulah Allah Subhanahu wata'alamenjanjikan bagi mereka surga". (Muttafaq Alaihi dari Mughirah radhiyallahu 'anhu)

\section{B. Al-Jannah}

Kata جن-يجنyang berarti menutup. Dan kata الجنة berasal dari fiil madhil dari akar kata (جن) janana yang berarti tertutup atau tidak kelihatan, dan perubahan kata menjadi (الجنة)aljinnah yang berarti jin adalah bentuk jamak dari kata (الجني) jinny, ditandai dengan (a) untuk menunujukkan bentuk jamak muannats. Kata jinn terambil pula dari akar kata (جن) janana yang berarti tertutup atau tidak kelihatan. Anak yang masih dalam kandungan dinamai (جنين) janin, karna ia tidak kelihatan dalam perut ibunya. Surga demikian juga hutan yang lebat, dinamai (الجنة)jannah, karna pandangan tidak dapat menembusnya.(مجنون) majnun, adalah orang gila/yang tertutup akalnya. Jannah, dinamai demikian, karena ia adalah syurga yang mana keenikmatan-kenikmatanya tidak terlihat/tertutup.

Contoh dalam sebuah pernyataan:

malam gelap gulita

Demikian pula Rasulullah Saw. bersabda:

$$
\text { الحج المبرور ليس له جزاء الا الجنة }
$$

Artinya:

"Haji yang mabrur tiadalah balasanya melainkan syurga".

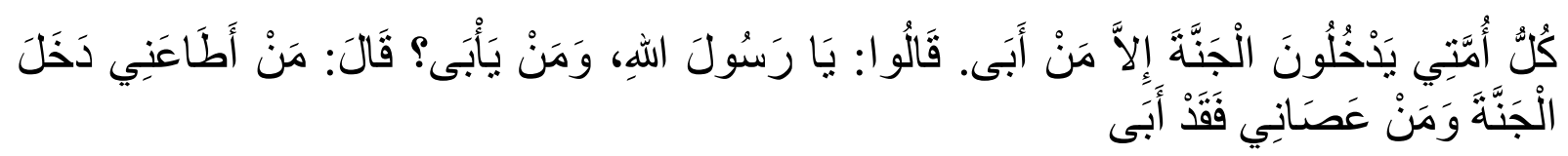

Artinya:

"Setiap umatku pasti masuk surga kecuali yang enggan." Mereka bertanya, "Siapa yang enggan, wahai Rasulullah?" Beliau menjawab, "Barang siapa taat kepadaku maka dia pasti masuk surga, dan barang siapa yang bermaksiat kepadaku maka dialah yang enggan". (HR. alBukhāri)

Adapun beberapa derivasinya yang penulis temukan sebagaimana tetera di atas yaitu:

\begin{tabular}{|c|c|}
\hline جنين & :bayi dalam perut ibunya \\
\hline جن ج ج & jin \\
\hline جن - جنون & :gila (hilang akal) \\
\hline
\end{tabular}




\section{C. $N a \dot{\bar{a}} r$}

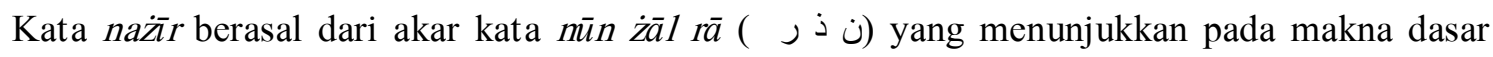
menakut-nakuti ( تخويف) maupun ketakutan ( تخؤف). Maka dari itu, bersumpah atas nama Allāh untuk melakukan sesuatu dimasa datang disebut dengan al-nażr (النذر) karena yang bersangkutan takut/khawatir jika sumpahnya tersebut tidak ditepati.5 Adapun inżār memiliki arti yang kurang lebih sama dengan kata iblāgh yakni penyampaian informasi. Bedanya, yang pertama hampir selalu digunakan untuk menyampaikan berita yang menakutkan.

Ibn Manżūr (630-711H), meriwatkan pendapat dari Kura' dan Al-Lihyāniy bahwa makna anżara berarti memberitahu secara mutlak (a'lama) disamping juga bermakna menakut-nakuti (khawwafa) dan memperingatkan (khażara)6 Sementara Al-Rāghib al-Asfahāniy menjelaskan bahwa kata al-nadzīr maupun al-mundzir adalah segala sesuatu yang dapat memberikan peringatan (inżār) baik berupa manusia ataupun bukan.7

Dari kajian diatas dapat disimpulkan bahwa kata inżàr lebih sering digunakan untuk mengartikulasikan pemberian peringatan atau informasi yang menakutkan, meskipun juga bisa berarti pemberian informasi secara mutlak. Atau dalam konteks beberapa ayat al-Qur'an bisa memiliki arti memberikan peringatan berupa pengajaran pesan-pesan agama Islam.

Rasulullah Saw. bersabda:

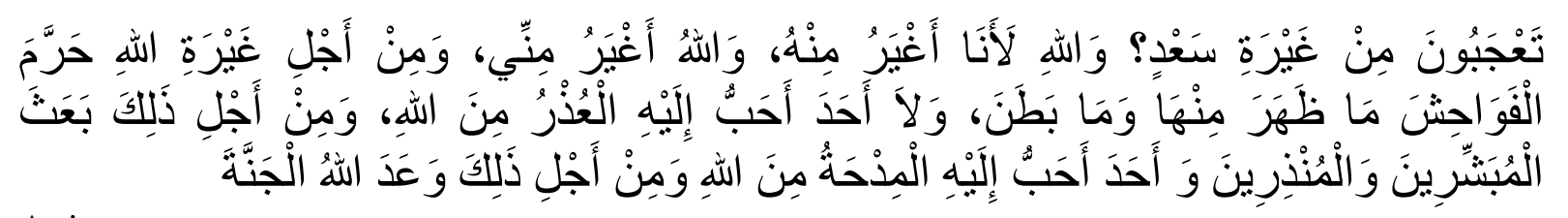

Artinya:

"Kalian merasa heran dengan kecemburuan Sa'd? Demi Allah, aku lebih cemburu darinya, dan Allah Subhanahu wata'alalebih cemburu dariku. Karena kecemburuan Allah Subhanahu wata'ala, Dia mengharamkan segala perbuatan keji yang tampak dan yang tersembunyi. Tiada satu pun yang lebih senang menerima uzur dari Allah Subhanahu wata'ala. Oleh karena itu, Dia mengut us para pembawa berita gembira dan pemberi peringatan, dan tidak satu pun yang paling menyenangi pujian dari Allah Subhanahu wata'ala, karena itulah Allah Subhanahu wata'alamenjanjikan bagi mereka surga". (Muttafaq Alaih dari Mughirah ra.)

\section{Al-Dhu'a',}

Dilihat dari konstruksi hurufnya, doa merupakan kata serapan yang diadopsi dari bahasa Arab, yaitu al-dua (الدعاء). Adapun dari sisi bentuk atau shighat (الصيغة)), lafadz al-dua (الدعاء) merupakan salah satu bentuk derivasi dalam bentuk mashdar (المصدر) yang di ambil dari lafadz (دعاء) - يدعو). Sedangkan kata kerja (دعا - يدعو) sendiri, termasuk ke dalam fiiltsulasi mujarrad, yaitu kata kerja yang terbentuk dari tiga huruf dal,ain, dan alif, dengan menyandang predikat bina mutal naqish.

5 Abū al-Husayn Ahmad ibn Fāris ibn Zakariyā, Maqāȳ̄s al-Lughah, Jilid 5, h. 414

6 Muhammad ibn Mukrim ibn Mandzūr al-Ifrīqiy al-Mishriy, Lisān al-'Arab, (Software Al-Maktabah Al-Shāmela Edisi 3.13), bab. Harf al-Rā',

7 Al-Husayn ibn Muhamad ibn Al-Mufadlal, Al-Rāghib Al-Asfahāni Abū al-Qāsim, Mufradāt Alfādh alQur'ān, (Software Al-Maktabah Al-Shāmela Edisi 3.13) bab. نذر 
Pembentukan lafadzmashdar al-du'a', (الدعاء) dari kata kerja (دعا - يدعو), mengikuti salah satu kaidah pembentukan mașdar sima Ifi ì suläśi mujarrad, yaitu apabila suatu lafáz mengandung arti

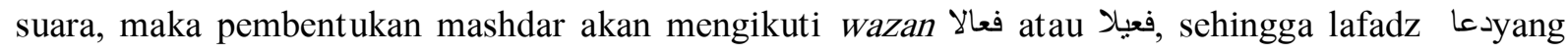

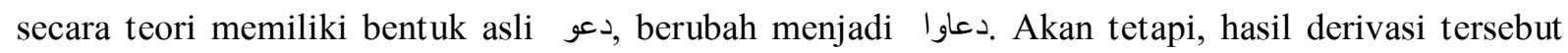
belum mencapai bentuk final. Hal ini dikarenakan, bentuk mashdar دعاو harus terbentur dengan ketentuan lain, yaitu apabila huruf wawu atau ya terletak sesudah huruf tambahan; huruf alif yang terletak setelah huruf ain, maka berdasarkan teori, huruf-huruf tersebut harus diganti dengan huruf hamzah. Dengan demikian, bentuk mashdar الدعاو الدعاء (الدعاء.

“Doa" (الدعاء) merupakan jenis lafadz yang memiliki makna lebih dari satu. Abu Jafar alThabari, salah seoarang pakar tafsir abad ke 3, memaparkan beberapa hal penting terkait dengan doa. Di dalam karya tafsirnya dijelaskan bahwa lafadz doa secara umum memiliki dua pengertian. Pertama, bahwa yang dimaksud dengan doa adalah segala bentuk amal yang diperintahkan oleh Allah, baik yang bersifat sunah ataupun wajib. Dengan kata lain, bahwa arti primer dari doa adalah ibadah. Hal ini senada dengan hadis Nabi:

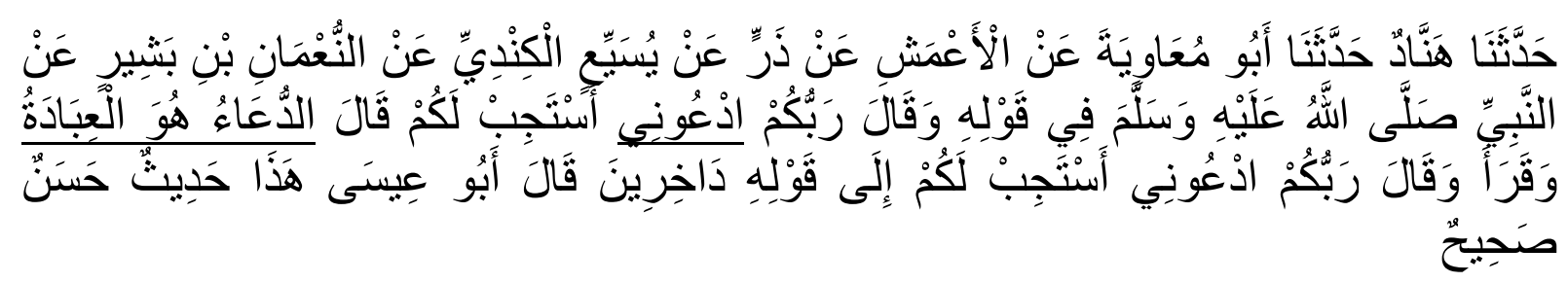

Artinya:

"Diriwayatkan dari Numan ibn Basyir, bahwa Rasulullah saw bersabda: Tuhanmu telah berkata "berdoalah kepadaku maka akan ku kabulkan”, Rasul berkata: doa adalah Ibadah".

Adapun pengertian kedua, menurut al-Thabari merupakan makna khusus dari kata doa. Dalam karya tafsirnya, ia tidak memberikan penjelasan secara terperinci terkait makna sekunder dari doa. Akan tetapi, informasi terkait hal ini terlengkapi dengan beberapa pandangan yang diberikan oleh para Ulama. Salah satunya yang dipaparkan oleh Abu al-Qasim al-Husain ibn Muhammad atau lebih dikenal dengan nama Al-Raghib al-Ashfahani (w. $502 \mathrm{H}$ ), seorang pakar dalam kosa kata al-Quran. Melalui karyanya; al-Mufradat fi Gharib al-Qur'an, ia menjelaskan bahwa kata doa di dalam al-Quran memiliki beberapa makna, di antaranya:

1. Penamaan (al-tasmiyyah)

2. Permohonan (al-sual)

3. Memohon perlindungan (al-istighā $\dot{s} a h)$

4. Bersedih hati karena penyesalan (al-Ta'ssuf)

5. Anjuran, dorongan (al-hass)

6. Penaikan derajat dan penghormatan (al-rifah wa al-tanwih) 
Kata الدعاء berasal dari fiil yang berarti menyeru, memanggil, mengajak, menjamu.الدعاءasalnya adalah bermaksud untuk memanjatkan doa kepada Allah swt, seperti dalam ungkapan menyatakan;" "دعا له الخير" mendoakan kebaikan kepadany, adapun perubahan menjadi kata yang berarti seruan, panggilan, ajakan, jamuan, dan isim fail dari kata ini adalahع دعوة yang berarti dai/muballigh.

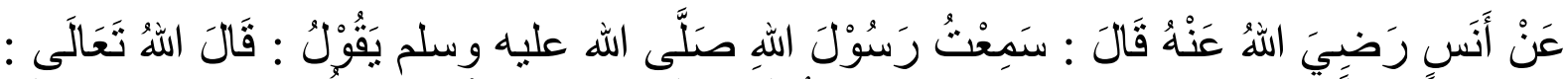

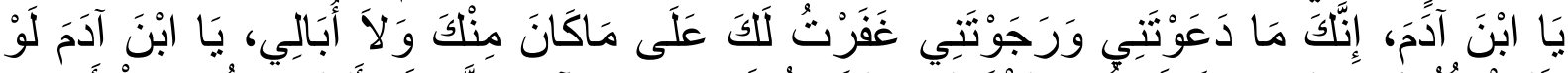

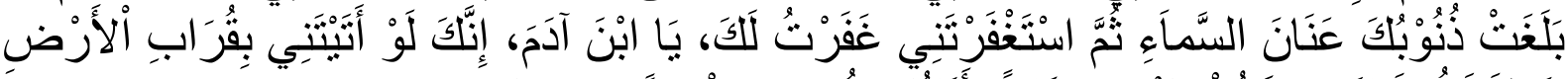
Artinya:

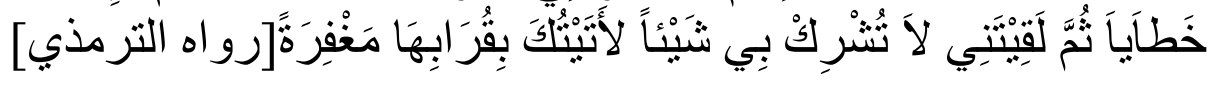

"Dari Anas Radhiallahuanhu dia berkata: Saya mendengar Rasulullah Shallallahu'alaihi wasallam bersabda: Allah Ta'ala berfirman: "Wahai anak Adam, sesungguhnya Engkau berdoa kepada-Ku dan memohon kepada-Ku, maka akan aku ampuni engkau, Aku tidak peduli (berapapun banyaknya dan besarnya dosamu). Wahai anak Adam seandainya dosa-dosamu (sebanyak) awan di langit kemudian engkau minta ampun kepada-Ku niscaya akan Aku ampuni engkau. Wahai anak Adam sesungguhnya jika engkau datang kepadaku dengan kesalahan sepenuh bumi kemudian engkau menemuiku dengan tidak menyekutukan Aku sedikitpun maka akan Aku temui engkau dengan sepenuh itu pula ampunan".

Pada hadis di atas terdapat beberapa kata دعاء yang memiliki makna berdoa, adapun pelajaran

yang terdapat dalam hadits di atas:

1. Berdoa diperintahkan dan dijanjikan untuk dikabulkan.

2. Pemberian maaf Allah dan ampunan-Nya lebih luas dan lebih besar dari dosa seorang hamba jika dia minta ampun dan bertaubat.

3. Berbaik sangka kepada Allah Ta'ala, Dialah semata Yang Maha Pengampun bagi orang yang bertaubat dan istighfar.

4. Membuka pintu harapan bagi ahli maksiat untuk segera bertaubat dan menyesal betapapun banyak dosanya.

\section{E. Al-Munkar}

نكر - ينكر ling berarti perkara-perkara yang keji yang tiada diridhoi Allah berasal dari fiil yang berarti tiada mengetahuiatau ankara (tiada mengakui menginkari) yangberarti sesuatu yang tidak dikenal,dalam ungkapan menyatakan نكر الرجل .

Adapun derivasi kata ini antara lain seperti:

\begin{tabular}{|c|c|}
\hline منكر و نكير & : nama dua malaikat yang menanyai dalam kubur \\
\hline 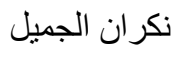 & : tiada membalas budi \\
\hline نكرة & : hal menginkari, samar, tak terang \\
\hline
\end{tabular}

Adapun dalam hadis Rasulullah saw menyatakan: 


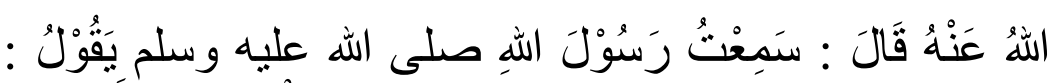

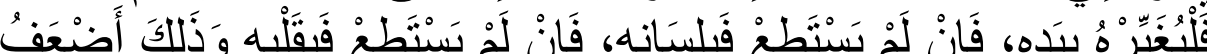

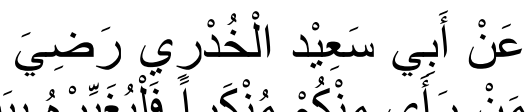

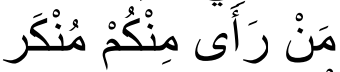

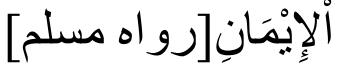

Artinya:

"Dari Abu Sa'id Al Khudri radiallahuanhu berkata : Saya mendengar Rasulullah shollallohu 'alaihi wa sallam bersabda: Siapa yang melihat kemunkaran maka rubahlah dengan tangannya, jika tidak mampu maka rubahlah dengan lisannya, jika tidak mampu maka (tolaklah) dengan hatinya dan hal tersebut adalah selemah-lemahnya iman". (Riwayat Muslim)

Dalam hadis ini kata منكر yang berarti menginkari perintah dan larangan Allah Swt. dan adapun pelajaran yang terdapat dalam hadis ini:

1. Menentang pelaku kebatilan dan menolak kemunkaran adalah kewajiban yang dituntut dalam ajaran Islam atas setiap muslim sesuai kemampuan dan kekuatannya.

2. Sabar menanggung kesulitan dan amar ma'ruf nahi munkar.

3. Amal merupakan buah dari iman, maka menyingkirkan kemunkaran juga merupakan buahnya keimanan.

4. Mengingkari dengan hati diwajibkan kepada setiap muslim, sedangkan pengingkaran dengan tangan dan lisan berdasarkan kemampuannya.

\section{F. Al-Tarbiyah}

kata tarbiyah adalah bentuk masdar dari fi'il madhi rabba, yang mempunyai pengertian yang sama dengan kata ' $r a b b$ ' yang berarti tuhan. Dalam hadits tidak ditemukan kata tarbiyah, tetapi ada istilah yang senada dengan itu yaitu; ar-rabb, rabbayani, murabbi, rabbiyun, rabbani. Sebaiknya dalam hadis digunakan istilah rabbani. Semua fonem tersebut mempunyai konotasi makna yang berbeda-beda.

Beberapa ahli tafsir berbeda pendapat dalam mengartikan kata-kata di atas. Sebagaimana dikutip dari Ahmad bahwa pendidikan merupakan arti dari kata tarbiyah kata tersebut berasal dari tiga kata yaitu; rabba-yarbu yang bertambah, tumbuh, dan 'rabiya- yarbaa' berarti menjadi besar, serta 'rabba-yarubbu' yang berarti memperbaiki, menguasai urusan, menuntun, menjaga, memelihara. Dalam literatur-literatur berbahasa Arab kata Tarbiyah mempunyai bermacam macam definisi yang intinya sama mengacu pada proses pengembangan potensi yang dianugrahkan pada manusia.

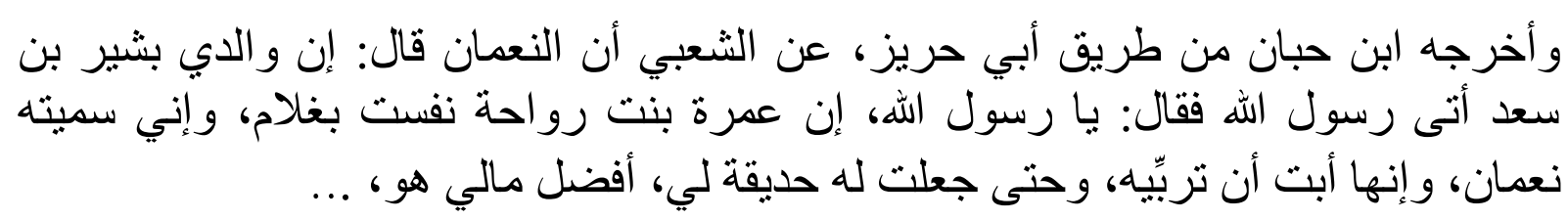

\section{G. Al-Nahy}

نهي- ينهي نerarti larangan berasal dari fiil. نهيتكم عن شيء derivasi kata ini نهاية berarti sudah,selesai, sempurnahan, penghabisan, dan yang melarang disebut ناهية.

Sabda Rasulullah Saw. menyatakan: 


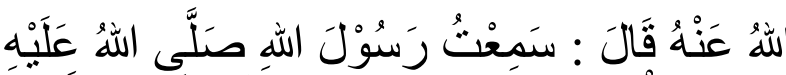

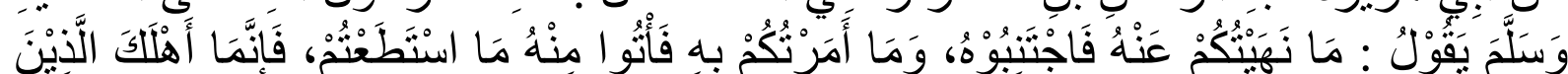

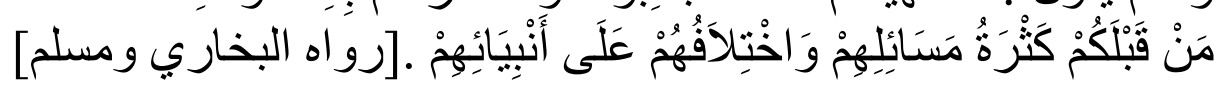

Artinya:

"Dari Abu Hurairah Abdurrahman bin Sakhr radhiallahuanhu dia berkata : Saya mendengar Rasulullah Shallallahu'alaihi wasallam bersabda : Apa yang aku larang hendaklah kalian menghindarinya dan apa yang aku perintahkan maka hendaklah kalian laksanakan semampu kalian. Sesungguhnya kehancuran orang-orang sebelum kalian adalah karena banyaknya pertanyaan mereka (yang tidak berguna) dan penentangan mereka terhadap nabi-nabi mereka". (Bukhori dan Muslim)

\section{Pelajaran dari kata نهي hadis di atas adalah :}

1. Wajibnya menghindari semua apa yang dilarang oleh Rasulullah Saw.

2. Siapa yang tidak mampu melakukan perbuatan yang diperintahkan secara keseluruhan dan dia hanya mampu sebagiannya saja maka dia hendaknya melaksanakan apa yang dia mampu laksanakan.

3. Allah tidak akan membebankan kepada seseorang kecuali sesuai dengan kadar kemampuannya.

4. Menolak keburukan lebih diutamakan dari mendatangkan kemaslahatan.

\section{G. Istiqāmah}

Kata قام - مقتوم yang berartitegak berdiriadapun kata ini mempunyai قو ام yang berarti yang betul,Iurus قيامةbangkit dari kubur, dari mati, itu sebabnya disebut hari kiamat القيامة, begitu pula kita sering menyebut دين القيمة Sمتقيم yang yang lurus, dan begitupula kata lurus, yang betul.

Rasulullah Saw. bersabda:

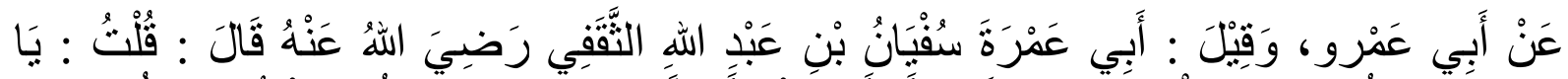

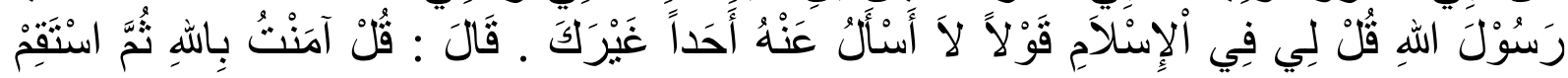
[رو اه مسلم

Artinya:

"Dari Abu Amr, -ada juga yang mengatakan- Abu "Amrah, Suufyan bin Abdillah Ats Tsaqofi radhiallahuanhu dia berkata, saya berkata : Wahai Rasulullah shollallohu 'alaihi wa sallam, katakan kepada saya tentang Islam sebuah perkataan yang tidak saya tanyakan kepada seorangpun selainmu. Beliau bersabda: Katakanlah: saya beriman kepada Allah, kemudian berpegang teguhlah". (Riwayat Muslim)

Kata استقام dalam hadits ini diartikan berpegang teguh dan adapun pelajaran yang bisa kita ambil dari hadits tersebut:

1. Iman kepada Allah ta'ala harus mendahului ketaatan.

2. Amal shalih dapat menjaga keimanan

3. Iman dan amal saleh keduanya harus dilaksanakan.

4. Istiqomah merupakan derajat yang tinggi. 
5. Perintah untuk istiqomah dalam tauhid dan ikhlas beribadah hanya kepada Allah semata hingga mati.

\section{H. al-Khalifah}

Kata khalifah, merupakan bentuk isim fá'il (pelaku) dari akar kata khalafa-yakhlufu, yang memiliki beberapa pengertian; mengganti, memberi ganti dan menempati tempatnya (dalam kamus al-Munawwir, halaman 362). Kata khalifah sendiri berpengertian: pengganti atau penguasa. itusebabnya abu bakar as-shiddiq disebut khalifah rasulullah yang menggantikan rasul menjadi pemimpin. Kata khilāfah merupakan bentuk infinitif (mașdar) dari kata khalafa, khilafah kebalikan dari salafa atau taqaddama yang berarti telah berlalu. Dalam hadis, berbagai derivasi kata khalafa digunakan dengan arti yang berbeda-beda seperti khalf, khalifah, khilaf, ikhtilaf, khalfah, yakhlif, akhlafa, yastakhlif dan iktilaf yang berarti persilisihan.

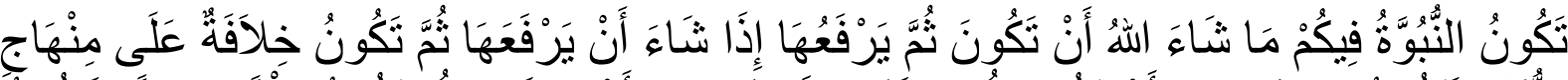

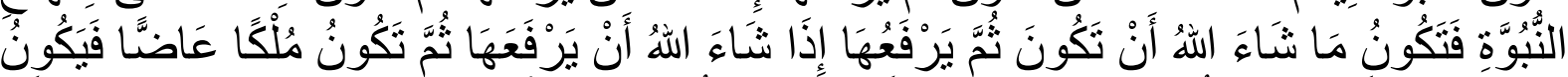

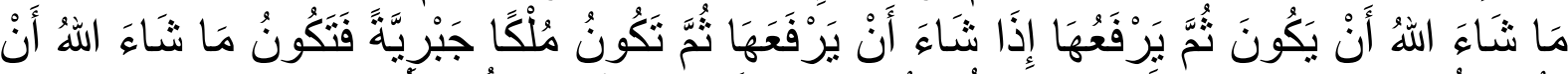

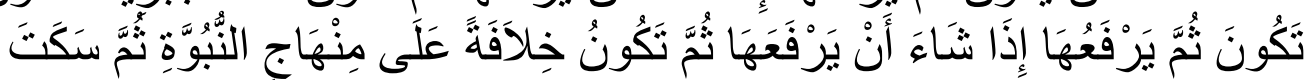

Artinya:

"Di tengah-tengah kalian terdapat zaman kenabian, atas izin Allah ia tetap ada. Lalu Dia akan mengangkatnya jika Dia berkehendak mengangkatnya. Kemudian akan ada Khilafah yang mengikuti manhaj kenabian. Ia ada dan atas izin Allah ia akan tetap ada. Lalu Dia akan mengangkatnya jika Dia berkehendak mengangkatnya. Kemudian akan ada kekuasaan (kerajaan) yang zalim; ia juga ada dan atas izin Allah ia akan tetap ada. Lalu Dia akan mengangkatnya jika Dia berkehendak mengangkatnya. Kemudian akan ada kekuasaan (kerajaan) diktator yang menyengsarakan; ia juga ada dan atas izin Alah akan tetap ada. Selanjutnya akan ada kembali Khilafah yang mengikuti manhaj kenabian." Beliau kemudian diam”. (HR Ahmad)

\section{Ta'Tim}

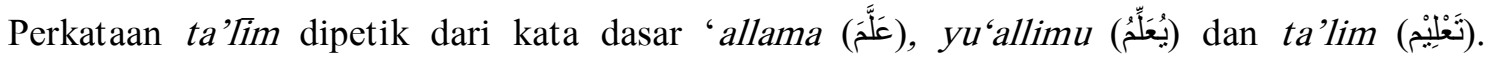
$Y u^{\prime}$ allimu diartikan dengan mengajarkan, untuk itu istilah ta'lim diterjemahkan dengan pengajaran. M. Thalib mengatakan bahwa ta'lim memiliki arti memberitahukan sesuatu kepada seseorang yang belum tahu.Istilah $\mathrm{Mu}$ 'allim atau pengajar yang berarti orang yang melakukan pengajaran, juga di munculkan dalam hadith, Nabi Muhammad Saw. bersabda:

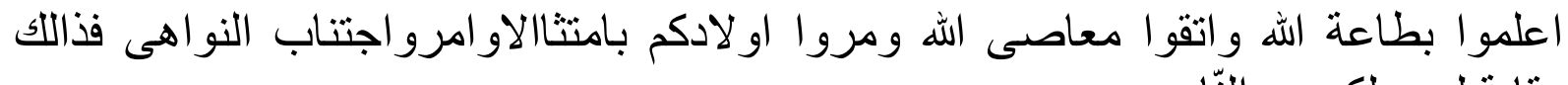

Artinya:

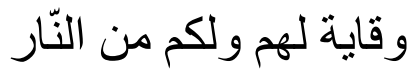

“Ajarkanlah mereka untuk ta'at kepada Allah dan takut berbuat maksiat kepada Allah serta suruhlah anak-anak kamu untuk menaati perintah-perintah dan menjauhi larangan-larangan. Karena itu akan memelihara mereka dan kamu dari api neraka".

Dalam hal ini ungkapan (اعملو) diberikan kepada orang tua yang berlaku sebagai mu'allim sedangkan pelajarnya (muta'allim) atau yang diajari adalah anak-anaknya. Juga sabda beliau: 
Artinya:

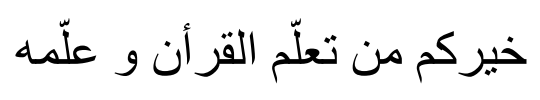

"Sebaik-baik kamu adalah orang yang mempelajari Al Qur'an dan mengajarkannya".

Dalam hadis ini secara lengkap disebutkan ungkapan ta'alum (تعلّم), sedangkan ilmu yang dipelajari adalah al-Qur'an serta disebutkan pihak yang mengajarkannya. Ta'lim secara umum hanya terbatas pada pengajaran dan pendidikan kognitif semata-mata. Hal ini memberikan pemahaman bahwa ta'lim hanya mengedepankan proses pengalihan ilmu pengetahuan dari pengajar (mu'alim) dan yang diajar (muta'alim). Ta'lim juga mewakili ungkapan proses dari tidak tahu menjadi tahu, istilah ta'lim menunjukkan bahwa ilmu yang bisa untuk dialihkan meliputi semua ilmu termasuk diantaranya sihir. Sehingga memang istilah tersebut lebih dekat pada pengajaran bukan pendidikan, karena pendidikan dalam pengertian Islam tentu saja harus mengarah pada manusia yang lebih baik, sesuai peran dan fungsinya di dunia ini.

Derivasi kata ini:

$$
\begin{array}{ll}
\text { علم علم علماء } & \text { : Ilmu } \\
\text { علامة } & \text { : Orang yang berilmu } \\
\text { علم } & \text { : Tanda }
\end{array}
$$

\section{KESIMPULAN}

Dari uraian diatas dapat disimpulkan bahwa leksikologi kata dalam hadis sangat ditentukan oleh lafaz-lafaz basȳir, al-jinnah, nażìr, al-du'ā', al-Munkar, tarbiyah, al-Nahy, al-Khalifah, dan ta'lim.

Kata basyīr dan beberapa derivasinya memiliki dua unsur makna kunci yaitu; (1) adanya proses menampakkan, memberitahukan, atau memberikan informasi, serta (2) sesuatu yang diinformasikan bersifat menggembirakan. Atau kalau kita mengambil pendapat al-Ṭabari terdapat unsur ketiga yaitu (3) informasi yang menggembirakan tersebut sebelumnya tidak diketahui oleh penerima.

Kata inżār lebih sering digunakan untuk mengartikulasikan pemberian peringatan atau informasi yang menakutkan, meskipun juga bisa berarti pemberian informasi secara mutlak. Atau dalam konteks beberapa ayat al-Qur'an bisa memiliki arti memberikan peringatan berupa pengajaran pesan-pesan agama Islam. Sedangkan kata ta'Tim secara umum hanya terbatas pada pengajaran dan pendidikan kognitif semata-mata. Hal ini memberikan pemahaman bahwa ta'tim hanya mengedepankan proses pengalihan ilmu pengetahuan dari pengajar (mu'alim) dan yang diajar (muta'alim).

\section{DAFTAR PUSTAKA}

Abū al-Ḥusain Aḥmad ibn Fāris ibn Zakariyā, Maqāȳ̄s al-Lughah, Tahqiq: Abd al-Salām Muhamad Hārūn, (Beirut, Dār Al-Fikr, 1979M/1399H). 
Al-Husain ibn Muhamad ibn al-Mufaḍ̣al, Abū al-Qāsim Al-Rāghīb Al-Asfahāni, Mufradāt Alfădh al-Qur'ān, (Software Al-Maktabah Al-Shāmela Edisi 3.13).

Muhamad ibn Jarīr ibn Yazīd ibn Kasīir bin Ghālib al-Amily, Abū Ja'far al-Thabary, Jāmi' al-Bayān fi Ta'wāl Al-Qur'ān, (Beirut, Muassasah al-Risālah, 2000), Juz. II.

Musțaf Ibrāhīm ā, dkk (Majma' Al-Lughah Al-Arabiyah Mesir), Al-Mu'jam Al-Wasith, (Istanbul, Dar al-Da'wah, 1989).

Muhammad ibn Mukrim ibn Mandzūr al-Ifrīqiy al-Mishriy, Lisān al-'Arab, (Software Al-Maktabah Al-Shāmela Edisi 3.13), bab. Harf al-Rā'. 